\title{
Analysis of stakeholder in the development of Labombo Beach sustainable town in Palopo City
}

\section{Analisis pemangku kepentingan dalam pengembangan wisata bahari Pantai Labombo secara berkelanjutan di Kota Palopo}

\author{
Muhammad Bibin, Yon Vitner, \& Zulhamsyah Imran \\ Faculty of Fisheries and Marine Sciences, Institut Pertanian Bogor \\ Jalan Agatis, Kampus IPB Dramaga Bogor, West Java 16680 \\ E-mail: muhammad.bibin01@gmail.com
}

\begin{abstract}
Labombo Beach is one of the main Palopo City natural tourism. This study aimed to understand the participation of stakeholder in the development of marine tourism in Labombo Beach. The stakeholders that included in this research are the governmental institutions, non-governmental organization, and social communities. Those stakeholders are being observed in drawing up policies for proper management and development in Labombo Beach tourist area. The method of this study is used two analytical approaches, qualitative stakeholder analysis and Analytical Hierarchy Process (AHP). The results showed that Tourism Department of Palopo City as a mandated agency in government affairs of tourism management and development in Palopo City as well as one of the key players which can fully engage other key players in formulating and evaluating the strategy of maritime tourism development of Labombo Beach. Tourism Department of Palopo City also maintaining a great communication and monitoring the existence of stakeholder actors group (A conscious group of youth lovers of nature and the environment of Palopo City and the community) because that their interests and influence can change in over time. The alternative development of Labombo Beach marine tourism which become the first priority is making tourism zoning, second is improving tourism facilities and infrastructure, third is conducting a tourism promotion and fourth is increasing the foster and train within the community.
\end{abstract}

Keywords: stakeholder; tourism zoning; marine tourism development

\begin{abstract}
Abstrak
Salah satu objek wisata alam andalan Kota Palopo adalah Pantai Labombo.Penelitian ini bertujuan untuk memahami partisipasi stakeholder terhadap pengembangan wisata bahari Pantai Labombo, memahami rencana pengembangan yang dilakukan oleh setiap stakeholder, yaitu institusi pemerintah, organisasi non-pemerintah, dan komunitas sosial. Stakeholder tersebut akan diamati dalam hal bagaimana mereka merumuskan kebijakan untuk pengelolaan dan pengembangan yang tepat pada kawasan wisata Pantai Labombo. Metode penelitian menggunakan dua pendekatan analisa, yaitu analisis stakeholder secara kualitatif dan analisis Analisis Hirarki Proses (AHP). Hasil penelitian menunjukkan bahwa Dinas Pariwisata Kota Palopo sebagai instansi yang diberikan mandat dalam urusan pemerintah dalam pengelolaan dan pengembangan wisata di Kota Palopo sekaligus sebagai salah satu stakeholder kunci (key players) dapat melibatkan secara penuh key players lainnya dalam merumuskan dan mengevaluasi strategi pengembangan wisata bahari Pantai Labombo. Dinas Pariwista Kota Palopo juga menjalin komunikasi dengan baik dan memonitor keberadaan stakeholder kelompok actors (kelompok sadar wisata ikatan pemuda pencinta alam dan lingkungan Kota Palopo dan masyarakat) karena kepentingan dan pengaruhnya bisa berubah seiring berjalannya waktu. Alternatif pengembangan wisata bahari pada kawasan Pantai Labombo yang menjadi prioritas pertama, yaitu membuat zonasi wisata, prioritas kedua, peningkatan sarana dan prasarana wisata, prioritas ketiga melakukan promosi wisata, dan prioritas keempat peningkatan pembinaan dan pelatihan pada masyarakat.
\end{abstract}

Kata kunci: pemangku kepentingan; zonasi; pengembangan wisata bahari

\section{Introduction}

Coastal natural resources have potential values that can be used for tourism activities. Tourism activity is an act of using natural resources that rely on nature services for human satisfaction. The tourism activities that developed with the concept of marine ecotourism can be grouped into two, those are coastal tourism and marine tourism. Coastal tourism is a tourism activity that prioritizes the 
coastal resources and culture of coastal communities. There are various functions of coastal tourism such as recreation, sports and enjoy the scenery. While marine tourism is a tourism activity that prioritizes underwater resources and the dynamics in the seawaters (Yulianda 2007).

Palopo city has a diversity of cultures and traditions and has a number of potential natural tourist sites, such as Labombo Beach, Songka Beach and Latuppa Tourism Village. The city is located at the northern tip of South Sulawesi province and located 326 KM from Makassar City. One of the marine tourism objects which are popular among the society of Palopo City is Labombo Beach that located in Salekoe Village Wara Timur Subdistrict which is $3 \mathrm{KM}$ from the center of Palopo City. Many people always visit Labombo Beach, particularly on Friday afternoon and Sunday there was a significant increase in visitor number.

The development of marine tourism in Labombo Beach is not only the responsibility of the government, but it requires an active role from all the stakeholders. According to Freeman (1994), the stakeholders are the people who influence or influenced by the decisions or actions. The tourism object development has several important components, such as the aspects of sustainable natural resource potential, financing the sources, technical and non-technical management aspects, as well as regulatory arrangements. In the regulation of the authority of coastal and marine tourism, the development requires an active participation from several parties, such as the government, nongovernmental organizations, and the community. The stakeholder engagement, in this case, has not been done thoroughly, but only a few parties that were involved in the planning and decision-making process, or in the aspects of tourism management and the development at the Labombo Beach. The assessment development plans and policy directives of each stakeholder are expected to be able to create tourism development in Labombo Beach in a sustainable development.

\section{Research Method}

Snowball method is used to determine the informant resource, moving from one informant to the other informant. The informants who are referred in this study consists of the leaders of each stakeholder including the Head of Tourism Office of Palopo City, Head of Department of Marine and Fisheries of Palopo City, Head of City Spatial Planning of Palopo, Head of Environmental Agency of Palopo City, Head of Bapedda City Palopo, Chairman of NGO Wallacea, Lurah Salokoe, and Chairman of the Awareness Group tour of the youth ties of creators of nature and the environment of Palopo City and community leaders. The data collection method that used in this research is primary data. It was done through an in-depth interview with semi-directive interview method. The interview was done by a semi-directional method where the informant was guided in the discussion by the researcher which related to the purpose of the research. This interview activity is intended to group the stakeholders based on the influence (power) and interests, and formulate the roles that can be done to support tourism development goals of Labombo Beach in a sustainable way.

The data collected then analyzed by using the qualitative stakeholder analysis techniques (Bracke et al. 2005, Reed et al. 2009, and Mayers 2005) and the Process Hierarchy Analysis techniques (Saaty 1993). Qualitative stakeholder analysis is used to explain the role of stakeholders in the development of Labombo Beach tourism Palopo City, the interests and influence (power) of each stakeholder in supporting the goal of sustainable tourism development. PHA analysis is used to obtain the general policy alternative for the development of tourism area.

\section{Stakeholder analysis}

According to Reed (2009), stakeholder analysis can be done in three ways: (1) stakeholders identification; (2) grouping and differentiating among the stakeholders; (3) investigating the relationship between the stakeholders. Ackermann \& Eden (2011), the method analysis in analysing the stakeholders is using influence matrix and the classification of the stakeholders was grouped into a key player, context setter, subject and crowd. Key players are the most active stakeholders in management because they have a high influence and interest in developing a project. Then for the 
subjects category is for the stakeholder who has relatively high importance but low influence. This type of stakeholders is supportive, have little capacity to change the situation, but they can affect others if they create alliances with other stakeholders and otherwise they can be influenced by other stakeholders as well. For the context setter group is a stakeholder who has high influence, but little interest. The last is the crowd, the stakeholder who has little influence and interest in the desired outcomes and became a consideration in the decision-making process. Nonetheless, the influence and importance will change from time to time, therefore all the stakeholders need to be carefully considered.

\section{Process Hierarchy Analysis (PHA)}

According to Saaty (1993), PHA method helps in solving a complex problem by structuring a hierarchy of criteria, stakeholders, outcomes by drawing considerations for developing weights or priorities. This method also combines the power of feeling and logic which concerned on various issues, then synthesizes the diverse considerations into outcomes that match with our expectations.

According to Marimin (2004), in solving a problem using PHA there are several principles that need to be understood. The first is to make the hierarchy, the complex system can be understood by breaking it into hierarchical elements, and then combining it. The second is the criteria and alternative assessment which done by pairwise comparisons. Third, in determining the priority, for each criterion and alternatives, it needs a pairwise comparison. The relative comparison values of all the alternative criteria can be adjusted to the predetermined judgment to generate weight and priority which are calculated by manipulating the matrix or by solving the mathematical equations.

\section{Tourist service supporters}

According to Damanik \& Weber (2006) a group of tourist support services is a business group that does not specifically offer tourism products and services, but often relies on tourists as a service user and the product. The government is one of the tourist support services since that they have authority in arranging, supplying and designing various infrastructure which related to the tourism needs. In addition, the government is responsible for determining the direction of the intended tour. Secondly, the local people, especially local people who live in tourist areas, become one of the key players in the tour, because, in fact, they are providing most of the attractions while determining the quality of tourism products. Moreover, the local people are the direct owners of tourism attractions that had been visited and enjoyed by the tourists. Third, non-governmental organizations (NGO) who conduct activities in the tourism areas before it developed. The activities that usually taken by the NGO were related to the conservation and the regulation of ownership and exploitation of the local natural resources. Besides that, the NGO were also co-operated and team up with the local society to improve the tourism object.

\section{The planning and managing of the tourism area}

According to Junaidi (2011), the tourism management planning is determined by the balance of potential natural resources ecotourism and the services within tourism object. Each tourism area requires a management plan that contains the target that needs to be achieved in the future. The management plan should contain the objectives, management actions, and financing the tourism object were required to achieve the management goals. It also has the guidance how to maximize the benefits and minimize management impacts, costs or risks.

According to Tuwo (2011), management planning must have a guide on how the involving of stakeholders can be put in the right place in every management activities. Since that the decision making in tourism area needs the involvement of various actors such as the government, local people, local society, tourist, private sectors as well as a scientist. In order to make sure that every stakeholder can contribute, there will need the arrangement of the stakeholders within management planning process. 


\section{Result and Discussion}

\section{Stakeholder identification}

The development of beach tourism in Palopo City involves nine stakeholders which coming from local government agencies, non-governmental organization, and social community groups. The results of the stakeholder identification who involved in the development of Labombo Beach tourism in Palopo City is presented in table 1.

Table 1.

List of stakeholders involved in the development of Labombo Beach tourism in Palopo City

\begin{tabular}{cll}
\hline No & \multicolumn{1}{c}{ Stakeholder } & Information \\
\hline 1 & Tourism and Cultural Department Palopo City & Local Government \\
2 & Marine and Fisheries Department Palopo City & Local Government \\
3 & $\begin{array}{l}\text { Regional Development and Planning Department } \\
\text { Palopo City }\end{array}$ & Local Government \\
4 & Layout and architect idea Palopo City & Local Government \\
5 & Environmental agency of Palopo City & Local Government \\
6 & Salokoe Headman & Local Government \\
7 & Tourism Awareness group of youth nature and & Community Group \\
8 & environmental lovers association of palopo City & Community Group \\
9 & Community Group & Society \\
\hline
\end{tabular}

\section{Tourism and Cultural Department Palopo City}

Tourism and Cultural office Palopo City is one of the government institutes in tourism management in Palopo City which has several influences and interests, especially in the tourism sector. The main task of the Tourism Department of Palopo City is carrying out the government duties in tourism and cultural sector, and other tasks that submitted by the Mayor. The activities that undertaken by the Department of Tourism and Culture of Palopo City is to promote, organize tourist and cultural events and guide to the community to the tourist attraction. Promotion activities that has been done by the Department of Tourism and Culture of Palopo City are to introduce or promote tourist attraction in Palopo City through printed media, such as brochures, newspapers, internet as well as participate in a regional event by setting up a tourist booth and show some natural tourism products and other events that being held on certain days such as local art performances and traditional ceremonies which affiliate with the local community groups.

\section{Marines and Fisheries Department of Palopo City}

Department of Marines and Fisheries Palopo City also has a high influence on tourism development in Palopo City. The activities that held by this institution are policy-making in order to make the sustainable development of tourism object, conducting supervision in tourism area as well as organize society development of the local people within the tourism area.

\section{Regional Development and Planning Department Palopo City}

Regional development planning department (Bapedda) of Palopo City is one of the stakeholders who have influence in arranging the plan and investment in tourism. Since that the Bapedda can determine how much budget will be directed to the tourism sector after analyzing the potential and investment opportunities. This is in accordance with the main task and function Bappeda of Palopo City in Local Regulation No. 4 of 2008. The activities that undertaken in relation to the tourism are the preparation of regional development plans and investments in sustainable tourism development project. 


\section{Layout, spatial, and environment agency of Palopo City}

Layout and Spatial Planning department is a government agency that focused on the layouting and arranging the area of Palopo City. This department has a role in the preparation of detailed plans for tourism management and development. Palopo City Environmental Agency is a stakeholder who has a role in supervision, environmental conservation as well as conducting society development of the local people in the tourism area.

\section{Salokoe Headman}

Salokoe Headman is one of the informants on the development of Labombo Beach tourism which is very aware of the conditions at Labombo Beach due to the location of the beach itself is located in Salokoe Village, East Wara Subdistrict. The role of Salokoe Headman is to conduct a surveillance and supervision in tourist areas, raise an awareness of the tourism to the community, as well as develop community organizations in the tourism sectors that aims to manage the tourism maximally. The headman most likely contributes himself to doing tourism promotion.

\section{Tourism Awareness Group (the youth nature and environmental lovers association Palopo City)}

Tourism Awareness Group (youth nature and environmental lovers association Palopo City) was founded by a group of youths from the Students in Palopo City which the goal was to increase community participation in the development of Labombo Beach tourism, provide counseling on tourism management and workshops in making handicrafts that can be sold as souvenirs to the tourists who visit Labombo beach.

\section{Non-Government Organization (NGO) Wallacea}

Non-Government Organization Wallacea is most likely engaged in improving the capacity of community institutions through mentoring activities. Therefore, the community can be more independent, provide the guidance towards the management and the development of sustainable tourism, and campaign in raising an awareness to the tourist when visiting tourism object.

\section{Local Society}

Local Society who are local communities has a very important role in tourism development. Their role and participation are to maintain the security in tourism areas, provide supporting facilities, such as food stalls, rental boats and tour guides. In addition to this, local people also participate in organizing various entertainments at the certain events. The informant community is a community leader in Salekoe urban village.

\section{Stakeholder Mapping}

The success of development in a region is strongly influenced by the increasing response from the stakeholders, so it can be known what and how the development activity can be implemented. Similarly, the development of tourism in the area of Labombo Beach will work well if it receives support and positive responses from the stakeholders. The stakeholders that consist of the community, government and non-government institutions are the parties that play a significant role in supporting the sustainable tourism development in the area of Labombo Beach.

The classification of stakeholders is distinguished by the level of influence and interest in sustainable tourism development in the Labombo Beach area. Measurement of stakeholder is important in sustaining marine tourism management in Labombo Beach area by using several variables such as stakeholder involvement, stakeholder benefit, stakeholder form of authority, stakeholder work program and stakeholder dependency level in continuing marine tourism development in Labombo Beach area. The stakeholder analysis is classified according to the level of influence and the importance of using matrix according to Reed et al. (2009) that can be seen in Graph 1. 


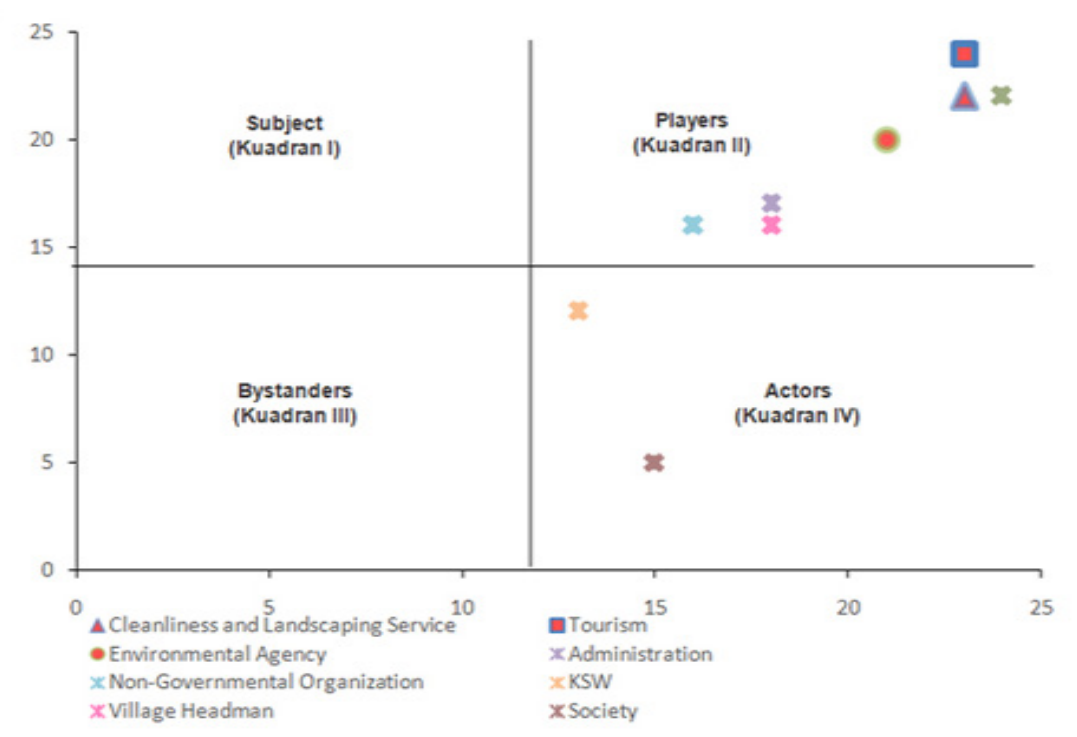

Graph 1.

Stakeholder classification according to the level of influence and importance

\section{Key players and actors}

Stakeholders with high interest and influence (power) are classified as players (Quadrant II). These stakeholders should be more actively involved (Reed et al. 2009) in evaluating a new strategy. The stakeholders including key players consist of Tourism Office, the Palopo City Maritime and Fishery Office, the Palopo City Bapedda, the Palopo City Environmental Agency, the Spatial and Cipta Karya Office of Palopo City, the Salokoe Village and the Wallacea NGO. The actor's group (in quadrant IV) is classified as low-interest stakeholders but own high power. This stakeholder can be quite risky and their roles need to be monitored and developed in an effective way (Reed et al. 2009). A good relation with this stakeholder has to be maintained. In addition, all of the information that needed has to be given out to them to keep their active role in order to achieve their goal. The stakeholder that classified as an actor in this research is The Society and Tourism Awareness Group of youth nature and environmental lovers' association Palopo City.

\section{Development planning of Labombo Beach tourism}

According to Gunn (1994) the states that have good tourist area, they usually succeed in preserving the environment including the natural resources. It is important to note that the ability of the stakeholder efforts in carrying strategy on spatial planning will be useful for the development of tourism object. According to Douvere (2008), the coastal marine layout and spatial planning aim to provide a strategic mechanism and an integrated plan based on an approach to marine management that allows for broader perspectives and to manage the potential conflicts, cumulative effects of human activities, and sea protection. The coastal and marine spatial planning provides opportunities not only to manage and understand the marine environment but also to enable a long-term planning in the processes to be more transparent, planning and allocation for both developers or governments and environmental managers. Coastal and marine tourism areas are well managed. To ensure the sustainability of resources it can be improved through the social and economic community welfare. The process of developing a better tourism management plan should consider the criteria of a good management plan which required an active involvement from the stakeholders. The short-term stakeholder plans in the development of Labombo Beach tourism can be seen in Table 2 .

In connection with the potential optimization of Labombo Beach area into an attractive and integrated tourism object along with served as locomotive and tourism icon of Palopo City. Therefore, in 
developing this Labombo Beach area it requires various programs that are direct, measured, clear and rational. Thus, this four things will be the foundation for preparing the development programs in order to achieve the goals and objectives of the development of Labombo Beach area in the future.

For the implementation stage of the program, being realistic is necessary particularly in looking at the various limitations of components when realizing the development programs. By observed carefully several aspects such as funding sources, personnel, organizational effectiveness, and other aspects, which then implemented the strategy through several stages. The planned is needed to realize all the programs that have been formulated and it is expected to take about five years. Afterwards, it is necessary to evaluate the results of the implementation, then formulate further concrete steps which are more actual and objective for the next stage of implementation that can run in accordance with the expectations and planning targets.

\section{The alternative strategic policy of sustainable tourism development}

Alternative Formulation policies for tourism development and sustainability in Labombo Beach area is using process hierarchy analysis (PHA). Based on Marimin (2004) the initial stage of the PHA method is the preparation of hierarchy or decomposition. Complex and unstructured problems are broken down into homogeneous groups and then compiled into a hierarchy through the process of decomposition. Each element at each level in the hierarchical structure is obtained through interviews with stakeholders and fill in the questionnaire. Questionnaire filling which aims to determine the priority of the continuity marine tourism development in Labombo Beach area given to the leader from each Stakeholder. Those are the head of Tourism Department Palopo City, the head of Marines and Fisheries Department Palopo City, the head of Layouting Department Palopo City, the head of Bappeda Palopo City, the head of Palopo City Environmental Agency, Salokoe Headman, the head of Wallacea NGO, the head of Tourism Awareness Group (youth nature and environmental lovers association Palopo City), and Local People leader as the informant.

The principle of appraisal in using AHP is by conducting paired comparisons with a matrix with a table to compare one element with another that against specific criteria. The scale 1-9 is set as a consideration in comparing the pairs of elements at each hierarchical level to another element that located at the top. The inconsistency ratio of each level from each expert must be less than 0.1. If the value is greater than 0.1 then the assessment needs to be revised or re-weighting by the relevant expert (Marimin 2004).

The hierarchical structure of the decision-making model of sustainable marine tourism development in Labombo Beach Area consists of three levels. Level 1 is the determination of the targets that need to be achieved for the continued development of marine tourism. Level 2 is the AHP structure as the main criteria or consideration for sustainable tourism development. The criteria that are being used are ecological, economic, social and institutional. Level 3 is a strategic alternative, in the continuing the development of marine tourism in Labombo Beach area, there are four development alternatives, those are making the zonation for a tourist area, tourism promotion, improvement of transportation access, improvement in coaching and training for the tourist service workers. In determining the development continuation of marine tourism in the area of Labombo Beach Kota Palopo is used criteria at the level 2, for alternative development at the level 3, and to achieve the goals or targets at the level 1 .

In determining the selection of sustainable tourism development in the area of Labombo Beach Palopo City. The comparison paired is on each ecological, social, economic and institutional criteria and then processed by using Microsoft Excel 2016. The result of pairwise comparison on each criterion can be known as the highest weight is the ecological criterion of 0,5439 (priority 1), which shows that it becomes the main priority in marine tourism development at Labombo Beach area. In the effort to develop marine tourism in Labombo Beach area to note the ecological aspects that include the condition of coral reefs, seagrass, mangrove, aquatic biota and water quality conditions. 
Then followed by social criterion with weight 0,2706 (priority 2 ) in the social criterion that is giving the facilities for tourist to be able to reach the tourism location both by land or sea. The economic criterion with weight 0,1219 (priority 3 ) is about increasing the number of tourist visits in the area of Labombo Beach which can give the advantages for the region. The last is the institutional criterion with the weight of 0.0892 (priority 4) is the development strategy of Labombo Beach tourism area through coastal community empowerment program. The analysis results of the selection criteria size can be seen in Graph 2.

Table 2.

Development plan of Labombo Beach tourist area

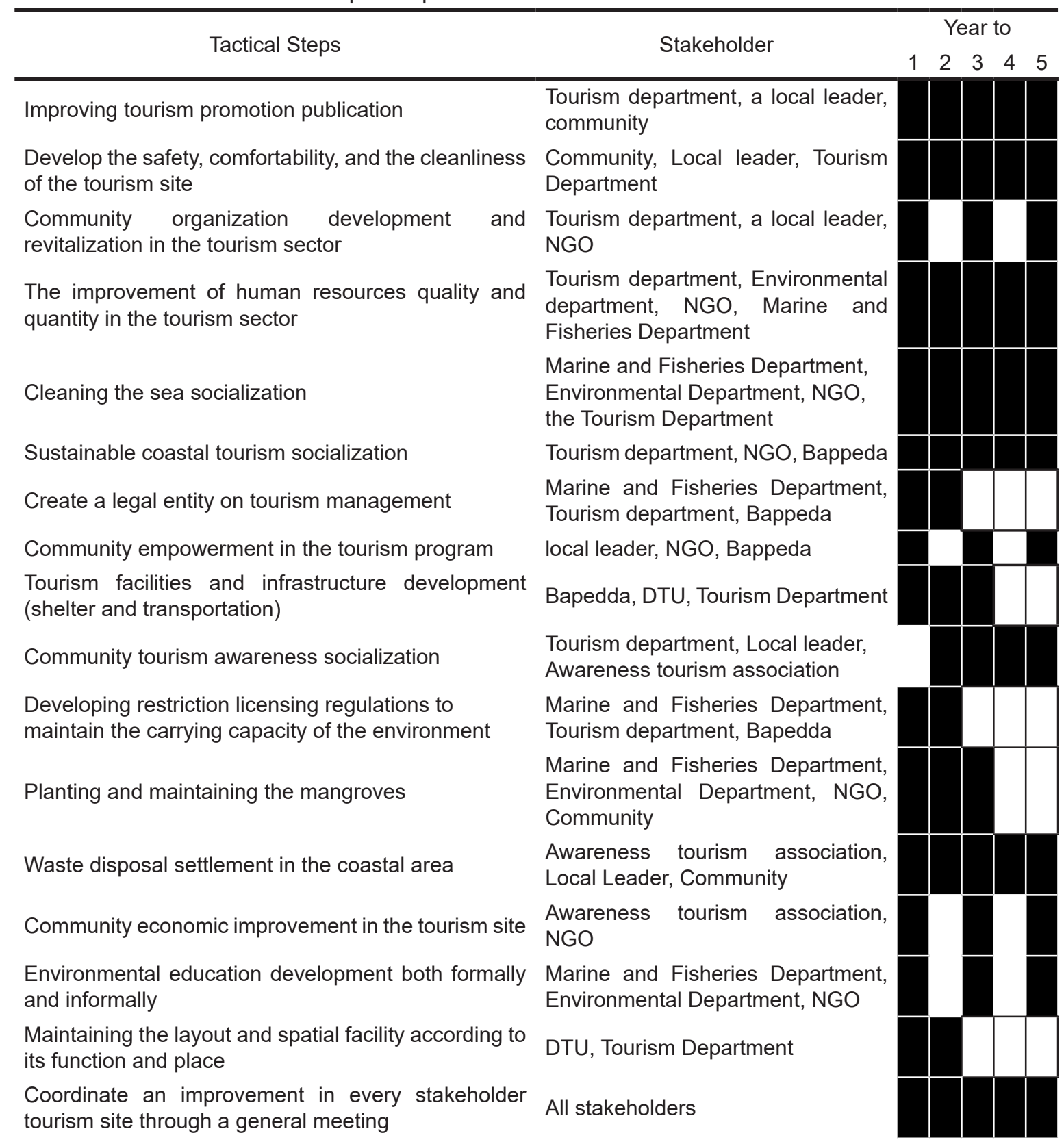

The weight obtained shows how different choices for criterion criteria by the stakeholder. The support levels for different strategy measurements will refer to alternate the future development scenarios that applied to illustrate the impact of different criteria priorities. The alternative scenarios of marine tourism development of Labombo Beach on a continuous basis with the main priority, namely: making zonation with weight 0.3956 , improvement of facilities and infrastructure with the weight of 0.3039 (priority 2), tourism promotion with weight 
0.1955 (priority 3) and increased training and coaching with a weight of 0.1049 (priority 4). The priority of alternative tourism development of Labombo Beach can be seen in graph 3.

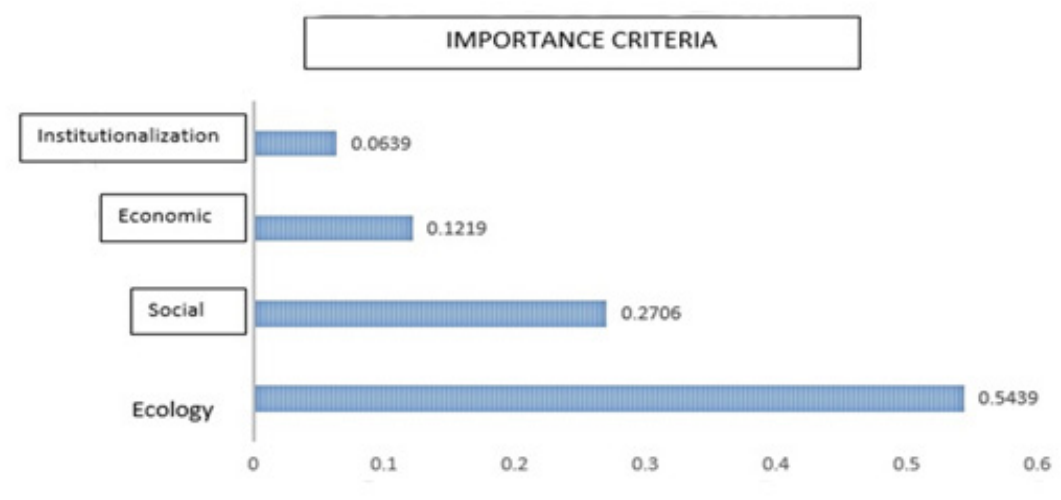

Graph 2.

Analysis result towards the selection of criteria size priority

TOURISM DEVELOPMENT ALTERNATIVES

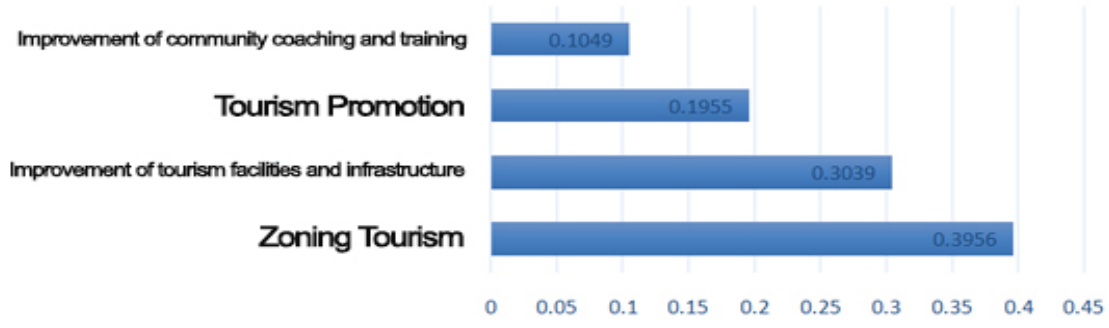

Graph 3.

Alternative strategy policy in tourism development

The priority in the development of marine tourism in the area of Labombo Beach is making the zonation system in the management of coastal and marine areas. Zoning system in tourist areas that pay attention to the principle of conservation is intended to maintain the balance of nature. A zoning system is an effort to protect natural resources and facilitate the implementation of management. Tourist zoning can be defined as the core zone, special zone, buffer zone and utilization zone. The second priority is the improvement of facilities and infrastructure which then makes the tourist able to visit the tourism object Labombo Beach easily and comfortably. The third priority is to promote tourism which not only sells the existing tourist attraction but also set the strategic target such as the satisfaction of visitors and loyal customers. The strategy must be integrated and qualified to be able to reach the targeted market. The promotion does not only make a brochure or advertise it, we need to think about a grand strategy or a promotion model with the new innovations to attract tourists to come and excited to visit again. The fourth priority is the improvement of coaching and training. Human resources are one of the basic capital in tourism development efforts since that the field of tourism should have the skills to provide tourism services and capable to handle various problems in the tour and the various problems.

\section{Conclusion}

The stakeholders who can be involved in the development of Labombo beach tourism consist of Tourism Department Palopo City, Marines and Fisheries Department Palopo City, Layouting Department Palopo City, Bapedda Palopo City, Palopo City Environmental Agency, Salokoe 
Headman, Wallacea NGO, Tourism Awareness Group (youth nature and environmental lovers association Palopo City), and Local People.

Each stakeholder has several programs and activities that can bring a positive impact on the sustainability of Labombo beach tourism development. Based on PHA analysis, the alternatives for the beach tourism development in Labombo beach area became the first priority in making the tourism zonation, the second priority is to increase tourism facilities, the third priority is conducting a tourism promotion and the fourth promotion is to increase the training and the development for the local society.

\section{References}

Ackermann F \& Eden C (2011) Strategic management of stakeholder: Theory and practice. Long Range Planning. 44:179-196.

Bracke MBM, De Greef KH \& Hopster H (2005) Qualitative stakeholder analysis for the development of sustainable monitoring systems for farm animal welfare. Journal of Agricultural and Environmental Ethics, 18:27-56.

Damanik J dan Weber HF (2006) Perencanaan Ekowisata. Yogyakarta (ID): Andi.

Djunaedi OS (2011) Sumber Daya Perairan Potensi Masalah dan Pengelolaan. Bandung: Widya Padjadjaran.

Douvere F (2008) The importance of marine spatial planning in advancing ecosystem-based sea use management. Marine Policy, 32:762-771.

Gunn C (1994) Tourism Planning: Basic Concepts and Cases, Edisi ke-3. Washington: Taylor \& Francis Publishers.

Marimin (2004) Teknik dan Aplikasi Pengambilan Keputusan Kriteria Majemuk. Jakarta: Grasindo.

Mayers J (2005) Analisis Kekuatan Stakeholder Dalam Manajemen Kalaborasi: Memahami Pluralisme Membangun Konsensus. In: Suporahardjo (ed). Bogor: Pustaka Latin.

Reed MS, Graves A, Dandy N, Posthumus H, Hubacek K, Morris J, Prell C, Quinn CH, \& Stringer, LC (2009) Who's in and why? A typology of stakeholder analysis methods for natural resource management. Journal of Environmental Management, 90:1933-1949.

Saaty TL (1993) Pengambilan Keputusan bagi Para Pemimpin Proses Hirarki Analitik untuk Pengambilan Keputusan dalam Situasi yang Kompleks. Jakarta: PT. Pustaka Binaman Pressindo.

Tuwo A (2011)Pengelolaan Ekowisata Pesisir dan Laut: Pendekatan Ekologi, Sosial Ekonomi, Kelembagaan dan Sarana Wilayah. Surabaya: Brilian Internasional.

Yulianda F (2007) Ekowisata bahari sebagai alternatif pemanfaatan sumberdaya pesisir berbasis konservasi. Seminar Sains pada Departemen Manajemen Sumber Daya Perairan, 21 Februari 2007. Bogor: Faculty of Fisheries and Marines Science, Bogor Agricultural Institute. 